\title{
Effect of Different Fertilizing Systems on Seed Yield and Phosphorus Uptake in Annual Medics under Dryland Farming Conditions
}

\author{
Ghobad SHABANI ${ }^{1}$, Mohammad Reza ARDAKANI ${ }^{1}$, Mohammad Reza CHAICHI ${ }^{2}$ \\ Juergen K. FRIEDEL ${ }^{3}$, Kazem KHAVAZI ${ }^{4}$, Hamid Reza ESHGHIZADEH ${ }^{5}$ \\ ${ }^{1}$ Agriculture Research Center, Karaj Branch, Islamic Azad University, Karaj, Iran; mohammadreza.ardakani@kiau.ac.ir \\ ${ }^{2}$ University of Tehran, College of Agriculture and Natural Resources, Karaj, Iran \\ ${ }^{3}$ University of Natural Resources and Life Sciences, Department of Sustainable Agricultural Systems, Vienna, Austria \\ ${ }^{4}$ Soil and Water Research Institute, Tehran, Iran \\ ${ }^{5}$ Ferdowsi University of Mashhad, College of Agriculture, Department of Agronomy, Mashhad, Iran
}

\begin{abstract}
The effect of different fertilizing systems on the seed yield and phosphorus uptake in annual medic (Medicago scutellata cv. 'Robinson') was examined at two locations under dry farming conditions in Kermanshah province, Iran, in 2009. Experiments were conducted based on a randomized complete block design with three replications; the treatments consisted of control (no fertilizer), chemical fertilizer, biological fertilizer and different combinations of chemical and biological fertilizing systems. The results showed that application of different fertilizing systems had a highly significant effect $(P<0.001)$ on the number of pods per plant. The highest values were obtained in the treatment using the urea chemical fertilizer + phosphorus-solubilizing bacteria + mycorrhiza. The highest soil seed bank was recorded in the nitrogen-fixing bacteria + phosphorus-solubilizing bacteria treatment; it increased the number of seeds by approximately 50 percent compared to the control (only 134 pod containing seeds). The highest pod yield was obtained after applying nitrogen-fixing bacteria + mycorrhiza $(445 \mathrm{~kg} / \mathrm{ha})$, the lowest yield in the control treatment $(266 \mathrm{~kg} / \mathrm{ha})$. In general, under the conditions of this experiment, the seed yield of annual medic var. 'Robinson' receiving nitrogen-fixing + phosphorus-solubilizing bacteria out-yielded other fertilizing treatments. This indicates a synergistic interaction between these groups of bacteria that increases seed yield, the soil seed bank as well as the seed phosphorus uptake of this plant species under dry farming conditions.
\end{abstract}

Keywords: annual medics, mycorrhiza, nitrogen-fixing bacteria, solubilizing bacteria

\section{Introduction}

In rotation with other agricultural crops, annual medics have a better water use efficiency; this feature makes them a suitable crop in rotation with wheat in dry climatic conditions (Weston, 1996). Establishing a wheat-annual medic rotation system, however, depends on a sufficiently high rate of seed production by annual medics. Experiments show that the success or failure of such a system is strongly related to seed production potential (Donald, 1967; Olsen and Sommers, 1990).

The term "soil seed bank" is applied to a set of seeds that remains intact and alive in the soil for various reasons such as seed hardiness or lack of suitable conditions for germination. A soil seed bank changes according to the growth conditions of different areas and the intensity and duration of grazing (Christiansen and Cocks, 1994). If the seed reserve in soil is below a threshold number of seedcontaining pods per square meter, then the natural regeneration of annual medic will not be successful (Kassaim, 1979). This criterion, however, varies with different medic species and varieties. Examples include Medicago rigidula (about 600 pods $/ \mathrm{m}^{2}$ ) and Medicago scutellata (250 pods/ $\mathrm{m}^{2}$; Francis, 1988).

Soil quality depends not only on its physical and chemical characteristics, but is also closely related to its biological activities (Ebhin Masto et al., 2006). Biological fertilizers, for example, are composed of different kinds of symbiotic microorganisms. Through biological processes they can change prime nutrients from an unavailable form to an available form, extend the root system and improve seed germination (Chen, 2006; Rajendran and Devaraj, 2004; Vessey, 2003).

Mycorrhizae improve the host plant's ability to absorb immobile nutrients, especially phosphorus and several other macronutrients. Mycorrhizae therefore improve the physical quality of the soil by extending the fungal mycelium, improve its chemical quality by promoting nutrient absorption, and improve its biological quality via the soil's nutritional network (Cardoso and Kuyper, 2006). A range of experiments has showed a synergetic interaction between mycorrhizae and rhizobia: their simultaneous 
192

inoculation with the plant increases plant phosphorus uptake and improves growth (Piccini and Azcon, 1987).

Mycorrhiza fungi moderate the adverse effects of drought. The symbiosis of the mycorrhiza with most crop roots under drought conditions improves crop productivity by absorbing more immobile nutrients such as phosphorus, zinc and copper. Moreover, crop drought tolerance is increased by improved water absorption and better leaf water potential, increased root length and depth, and developing terminal hyphae (Al-Karaki et al., 2003; Vamerali et al., 2003). Mycorrhizae improve the interaction between water and the host plant by increasing the soil's hydraulic conductivity, increasing the perspiration ratio, and decreasing stomata resistance by changing the crop's hormonal balance. These changes improve the phosphorus uptake by mycorrhizal-inoculated crops under drought conditions (Elwan, 2001). Under humid conditions, the hydraulic conductivity of root systems was higher in mycorrhizal-inoculated crops versus non-mycorrhizal crops. This was due to the increased root length of the former (Zahra and Loynachan, 2003). Nadian et al. (1998) reported that the dry matter of mycorrhizal-inoculated berseem clover was significantly higher than the control. Applying Rhizobium sp. bacteria along with the mycorrhiza fungi increased clover growth: both the shoot dry matter and the leaf area index increased by a factor of five. Newman and George (2004) found no significant differences in the phosphorus content of mycorrhizal and non-mycorrhizal crops.

Joint inoculation of Azotobacter and Rhizobium increases faba bean yield as well as mineral elements (Rodelas, 1999). Piccini and Azcon (1987) examined the effect of phosphate-solubilizing bacteria and mycorrhizal fungi on alfalfa and reported that applying phosphate-solubilizing bacteria increased the absorption of potassium and phosphorus nutrients as well as the biological yield of alfalfa.

There is a need to manage plant nutrition to increase and stabilize the yield in dry farming systems. At the same time, there is a need to conserve the environment. No research, however, has been done on the effect of biological fertilizers on the growth, yield, and conservation of the soil seed bank of annual medic. The present experiment was therefore designed to study the effect of different fertilizing systems on the pod and seed yield as well as on the phosphorus uptake in annual medic (Medicago scutellata var. 'Robinson').

\section{Material and methods}

This experiment was conducted in two locations during the 2009 growing season: 1. Sararood Dryland Farming

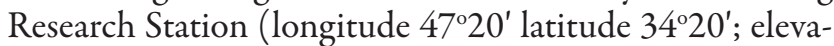
tion $1351 \mathrm{~m}$ above sea level), and 2. Mahidasht Soil Fertility Research Station (longitude 46 $6^{\circ} 50^{\prime}$ latitude $24^{\circ} 16^{\prime}$; elevation $1380 \mathrm{~m}$ above sea level). Selected physical and chemical characteristics of soil and climatic information of two experimental sites are shown in Tab. 1 and 2.

The experimental sites in both locations were kept as fallow in the preceding year. The experiment was conducted in the form of a randomized complete block design with three replications. Soil samples were collected prior to the experiment. The experimental treatments consisted of control (without fertilizer), chemical, biological and integrated fertilizing systems as follows:

$\mathrm{T}_{0}$ : Control (no fertilizer application)

$\mathrm{T}_{1}^{0}$ : Chemical fertilizer $(135 \mathrm{~kg} / \mathrm{ha}$ urea fertilizer +185 $\mathrm{kg} / \mathrm{ha}$ triple superphosphate fertilizer)*

$\mathrm{T}_{2}$ : Urea chemical fertilizer + phosphorous-solubilizing bacteria

$\mathrm{T}_{3}$ : Urea chemical fertilizer + mycorrhiza

$\mathrm{T}_{4}^{3}$ : Urea chemical fertilizer + phosphorous solubilizing bacteria + mycorrhiza

$\mathrm{T}_{5}$ : Nitrogen-fixing bacteria + triple superphosphate fertilizer

$\mathrm{T}_{6}$ : Nitrogen-fixing bacteria + phosphorous-solubilizing bacteria

$\mathrm{T}_{7}$ : Nitrogen-fixing bacteria + mycorrhiza

$\mathrm{T}_{8}$ : Nitrogen-fixing bacteria + phosphorous-solubilizing bacteria + mycorrhiza

${ }^{*}$ Chemical fertilizers triple superphosphate and urea were applied according to a soil test to fulfill the requirements of the crop in each site.

Tab. 1. Selected physical and chemical characteristics of soil (0$30 \mathrm{~cm}$ depth) in two experimental sites

\begin{tabular}{ccc}
\hline \multirow{2}{*}{ Characteristic } & \multicolumn{2}{c}{ Experimental stations } \\
\cline { 2 - 3 } & Sararood & Mahidasht \\
\hline $\mathrm{pH}$ & 7.68 & 7.93 \\
Dissolved solids $(\mathrm{EC} .103)$ & 30.0 & 55.0 \\
\hline Organic carbon (\%) & 0.31 & 0.62 \\
$\mathrm{CaCO}_{3}(\%)$ & 30 & 28 \\
\hline Olsen phosphorus $\left(\mathrm{mg} \mathrm{kg}^{-1}\right)$ & 8.00 & 9.40 \\
Available potassium $\left(\mathrm{mg} \mathrm{kg}^{-1}\right)$ & 530 & 430 \\
\hline DTPA extractable $\mathrm{Zn}\left(\mathrm{mg} \mathrm{kg}^{-1}\right)$ & 0.38 & 1.56 \\
DTPA extractable $\mathrm{Cu}\left(\mathrm{mg} \mathrm{kg}^{-1}\right)$ & 0.70 & 1.40 \\
\hline DTPA extractable Fe $\left(\mathrm{mg} \mathrm{kg}^{-1}\right)$ & 2.00 & 4.76 \\
\hline DTPA extractable $\mathrm{Mn}\left(\mathrm{mg} \mathrm{kg}^{-1}\right)$ & 2.42 & 3.78 \\
\hline Soil texture & Loamy silt & Loamy clay \\
\hline
\end{tabular}

Land preparation took place before sowing annual medic in early March. All experimental plots consisted of 6 planting rows that were $5 \mathrm{~m}$ long and $25 \mathrm{~cm}$ apart. The annual medic var. 'Robinson' was planted at a rate of 20 $\mathrm{kg}$ of seed/ha. Before sowing, based on soil analysis and according to fertilizer recommendations for annual medic, half of the urea fertilizer and all of the phosphorus fertilizer (in treatments containing phosphorus chemical fertilizer) were applied to the soil. Nitrogen and phosphorus chemi- 
Tab. 2. Climatic information for the two experimental sites during the annual medic growing season

\begin{tabular}{ccccc}
\hline \multirow{2}{*}{ Month } & $\begin{array}{c}\text { Average precipitation } \\
(\mathrm{mm})\end{array}$ & \multicolumn{2}{c}{$\begin{array}{c}\text { Average temperature } \\
\left({ }^{\circ} \mathrm{C}\right)\end{array}$} \\
\cline { 2 - 5 } & Sararood & Mahidasht & Sararood & Mahidasht \\
\hline Feb. & 18.3 & 21.2 & 7.3 & 6.4 \\
Mar. & 36.1 & 71.8 & 9.4 & 8.0 \\
Apr. & 15.2 & 12.4 & 16.2 & 14 \\
May & 0.2 & 0.9 & 22.7 & 19.7 \\
Jun. & 0 & 0 & 26.5 & 24.0 \\
\hline
\end{tabular}

cal fertilizers were applied to the soil in bands. The remainder of the nitrogen fertilizer was applied to each plot when the plants reached the four-leaf stage, respectively.

After calculating the number of seeds per treatment, the seeds were placed into a polyethylene bag $(30 \mathrm{mg}$ of each inoculation substance for $100 \mathrm{~g}$ of seed) along with $4 \%$ Arabic gum solution. The seed and the adhesive substance were then gently shaken for $30 \mathrm{~s}$. One gram of inoculation substance was added to the adhesive seeds and shaken for $45 \mathrm{~s}$, ensuring that the inoculation substance was uniformly distributed among the seeds.

At the end of experimental period, soil samples were randomly taken from 0 to $5 \mathrm{~cm}$ depth in each plot in both experimental locations using an auger to measure the soil seed bank. The soil samples were taken to the laboratory and, after segregating the seeds from the soil, passed through sieve numbers 8 and 10; this removed all impurities. The samples were again passed through sieve numbers 8 and 10, which were stacked, to separate the particles. The soil was washed through the sieves repeatedly until the water became clear. In order to verify that no seeds were left among the gravel and sand in the container, the contents were placed in $25 \%$ saline water and the seeds floating on the surface of the salt water were collected. The soil seed bank population was determined after gathering the seeds from the salt water surface. Pod phosphorus content was measured spectrophotometrically using the method of $\mathrm{Ol}$ sen and Sommers (1990).

The data were analyzed using the SAS software package. An analysis of variance was performed for each trait using the GLM procedure to test the significance of differences among locations, treatments and location by treatment interactions. Comparisons of all means were done at the 5 percent probability level based on a least significant difference (LSD) method.

\section{Results and discussion}

\section{Pod number perplant}

Applying different fertilizing systems had a highly significant effect $(P<0.001)$ on the number of pods per plant (Tab. 3). The highest values were obtained in the treatment using the urea chemical fertilizer + phosphorus-solubilizing bacteria + mycorrhiza $\left(\mathrm{T}_{4}\right)$, followed by that using nitrogen-fixing bacteria + mycorrhiza $\left(\mathrm{T}_{7}\right)$ and nitrogen-fixing bacteria + phosphorus-solubilizing bacteria + mycorrhiza $\left(T_{8}\right)$. Significantly fewer pods were recorded in the control treatment $\left(\mathrm{T}_{0}\right)$ compared to other treatments. Overall, applying the $T_{4}$ fertilizing system increased the amount of pods in the plant by $28.2 \% \mathrm{com}$ pared to the control (Tab. 4). This points to a synergistic effect between chemical fertilizer and the application of phosphorus- solubilizing bacteria and mycorrhiza on pod development in annual medic. Studies on sugar beet and barley growth and development show a similar positive effect of chemical fertilizer application along with inoculation with phosphorus-solubilizing and nitrogen-fixing bacteria (Ferrettin et al., 2004).

The interaction effects indicated significant differences between traits in the two experimental sites. The highest number of pods per plant was recorded in $\mathrm{T}_{7}$ in Sararood and $\mathrm{T}_{8}$ in Mahidasht (significantly higher than in the other treatments). The treatments including integrated fungi and bacteria components had synergistic effects on the number of pods per plant in annual medic.

The better climatic conditions at the Mahidasht site (more and better distribution of rainfall, moderate temperature; Tab. 2) caused a better response in the number of pods per plant to most fertilizer treatments compared to the Sararood site; exception: $T_{7}$ treatment).

\section{Soil seed bank}

The, soil seed bank was significantly influenced by the experimental sites and different fertilizing treatments ( Tab. 3 and 4). The highest soil seed bank was recorded in the nitrogen-fixing bacteria + phosphorus solubilizing bacteria $\left(\mathrm{T}_{6}\right)$ treatment, which increased the number of seeds by approximately $50 \%$ compared to the control (only 134 pods containing seeds; Tab. 4). Applying a combination of nitrogen-fixing bacteria + phosphorus-solubilizing bacteria intensified the effect of the fertilizer, improved crop growth and ultimately increased the soil seed bank. Comparing the two experimental sites also showed that the soil

Tab. 3. The Anova of annual medic agronomic characteristics as affected by different fertilizing systems under dry farming conditions (experimental sites: Sararood and Mahidasht Experimental Stations)

\begin{tabular}{cccccccc}
\hline \multirow{2}{*}{ SOV } & Df & Pods per plant & Soil seed bank & 100-seed weight & Pod yield & P-concentration & P-uptake \\
\cline { 3 - 8 } & & \multicolumn{7}{c}{$\operatorname{Pr}>\mathrm{F}$} \\
\hline Location (L) & 1 & $<0.0001$ & $<0.0001$ & $<0.0001$ & $<0.0001$ & 0.0013 & $<0.0001$ \\
Treatment (T) & 8 & 0.0006 & $<0.0001$ & $<0.0001$ & $<0.0001$ & $<0.0001$ & $<0.0001$ \\
L $^{*} \mathrm{~T}$ & 8 & $<0.0001$ & 0.0003 & $<0.0001$ & $<0.0001$ & $<0.0001$ & $<0.0001$ \\
\hline
\end{tabular}


Tab. 4. The effect of different fertilizing systems on seed characters at the two experimental research stations

\begin{tabular}{|c|c|c|c|c|c|c|c|c|c|}
\hline \multirow{3}{*}{ Treatment } & \multicolumn{3}{|c|}{ Pods per plant (no) } & \multicolumn{3}{|c|}{ Soil seed bank (no/m²) } & \multicolumn{3}{|c|}{ 100-seed weight $(\mathrm{g})$} \\
\hline & \multicolumn{2}{|c|}{ Location } & \multirow{2}{*}{ Mean } & \multicolumn{2}{|c|}{ Location } & \multirow{2}{*}{ Mean } & \multicolumn{2}{|c|}{ Location } & \multirow{2}{*}{ Mean } \\
\hline & $\mathrm{L}_{1}$ & $\mathrm{~L}_{2}$ & & $\mathrm{~L}_{1}$ & $\mathrm{~L}_{2}$ & & $\mathrm{~L}_{1}$ & $\mathrm{~L}_{2}$ & \\
\hline $\mathrm{T}_{0}$ & 7.80 & 8.70 & $8.25^{\mathrm{b}}$ & 130 & 137 & $134^{\mathrm{d}}$ & 15.5 & 24.2 & $19.8^{\mathrm{ab}}$ \\
\hline $\mathrm{T}_{1}$ & 8.43 & 10.8 & $9.63^{\mathrm{bcd}}$ & 198 & 250 & $224^{b c}$ & 15.3 & 19.6 & $17.4^{\mathrm{bc}}$ \\
\hline $\mathrm{T}_{2}$ & 7.60 & 10.6 & $9.12^{\mathrm{cd}}$ & 195 & 227 & $211^{\mathrm{bc}}$ & 13.3 & 20.0 & $16.6^{\mathrm{cd}}$ \\
\hline $\mathrm{T}_{3}$ & 8.43 & 9.83 & $9.13^{\text {cd }}$ & 185 & 205 & $195^{\mathrm{c}}$ & 13.4 & 18.5 & $15.9^{\mathrm{cdc}}$ \\
\hline $\mathrm{T}_{4}$ & 10.2 & 12.7 & $11.5^{\mathrm{a}}$ & 176 & 315 & $245^{\mathrm{ab}}$ & 14.4 & 14.4 & $14.4^{\text {def }}$ \\
\hline $\mathrm{T}_{5}$ & 8.63 & 9.00 & $8.81^{\mathrm{d}}$ & 209 & 255 & $232^{\mathrm{abc}}$ & 9.9 & 15.6 & $12.7^{\mathrm{f}}$ \\
\hline $\mathrm{T}_{6}$ & 8.50 & 12.3 & $10.4^{\mathrm{abc}}$ & 280 & 258 & $269^{a}$ & 10.0 & 16.4 & $13.2^{\mathrm{cf}}$ \\
\hline $\mathrm{T}_{7}$ & 12.4 & 8.70 & $10.5^{\mathrm{ab}}$ & 185 & 279 & $232^{\mathrm{abc}}$ & 25.4 & 16.1 & $20.7^{a}$ \\
\hline $\mathrm{T}_{8}$ & 8.40 & 12.9 & $10.6^{\mathrm{ab}}$ & 157 & 311 & $234^{\mathrm{ab}}$ & 14.0 & 16.9 & $15.4^{\text {ddf }}$ \\
\hline Mean & $8.94^{\mathrm{b}}$ & $10.6^{\mathrm{a}}$ & & $191^{\mathrm{b}}$ & $248^{a}$ & & $14.6^{\mathrm{b}}$ & $17.9^{\mathrm{a}}$ & \\
\hline $\mathrm{LSD}_{\text {local'trear }}(5 \%)$ & & & & & & & & & \\
\hline
\end{tabular}

$\mathrm{T}_{0}$ : Control (no fertilizer application); $\mathrm{T}_{1}$ : Chemical fertilizer $\left(135 \mathrm{~kg} / \mathrm{ha}\right.$ urea fertilizer $+185 \mathrm{~kg} / \mathrm{ha}$ triple superphosphate fertilizer); $\mathrm{T}_{2}:$ Urea chemical fertilizer + phosphorus-solubilizing bacteria; $\mathrm{T}_{3}$ : urea chemical fertilizer + mycorrhiza; $\mathrm{T}_{4}$ : urea chemical fertilizer + phosphorus-solubilizing bacteria + mycorrhiza; $\mathrm{T}_{5}$ : Nitrogen -fixing bacteria + triple superphosphate fertilizer; $\mathrm{T}_{6}$ : Nitrogen-fixing bacteria + phosphorus-solubilizing bacteria; $\mathrm{T}_{7}$ : nitrogen-fixing bacteria + mycorrhiza;

$\mathrm{T}_{8}$ : Nitrogen-fixing bacteria + phosphorus-solubilizing bacteria + mycorrhiza

seed bank was significantly influenced by the experimental locations (Tab. 3). Annual medic in Mahidasht had a larger soil seed bank than Sararood (Tab. 4). The treatment using nitrogen-fixing bacteria + phosphorus-solubilizing bacteria $\left(\mathrm{T}_{6}\right)$ produced the richest soil seed bank (269 pods $/ \mathrm{m}^{2}$ ). Because of more in rainfall (Tab. 2), the soil seed banks contained more pods at Mahidasht than at Sararood. The fertilizing systems in annual medic must be adjusted such that the plant can produce a sufficient amount of seed to create a rich soil seed bank to ensure its natural regeneration. The critical limit for a successful re-establishment of annual medic in a ley farming system for Medicago scutellata is an average of $250 \mathrm{pods} / \mathrm{m}^{2}$. This critical limit, however, varies with different species and types of annual medic. For Medicago rigidula and Medicago scutellata, for example, approximately 600 and 250 pods $/ \mathrm{m}^{2}$, respectively, are sufficient (Francis, 1988). In this experiment the treatment using nitrogen-fixing bacteria + phosphorus-solubilizing bacteria $\left(\mathrm{T}_{6}\right)$ enabled sufficient seed production and a rich soil seed bank for successful natural regeneration; it stood out among the other fertilizing treatments in this respect. Applying a combination of different fertilizing systems containing bacteria and mycorrhiza had a positive effect on annual medic growth and seed production in our experiment. These results are supported by Wasule et al. (2002), who observed the synergistic effect of applying the nitrogen-fixing symbiotic bacteria Brady rhizobium and the phosphate-solubilizing bacteria Pseudomonas putida on soybean.

The interaction effect of fertilizing treatments and experimental sites indicated that the $\mathrm{T}_{4}$ treatment produced the highest number of pods in the soil seed bank in Mahidashte, whereas the $\mathrm{T}_{6}$ treatment created the richest soil seed bank in Sararood. The better soil seed reserves in Mahidash versus Sararood under all different fertility treatments can be explained by the more favorable climatic conditions in the former site (greater mean annual precipitation).

\section{0-seed weight}

The effect of fertilizing treatments on the weight of 100 seeds was significant $(\mathrm{P}<0.05)$ (Tab. 3). The heaviest weight was obtained in $\mathrm{T}_{7}$ (nitrogen-fixing bacteria + mycorrhiza)(20.7 g; Tab. 4). This probably reflects the beneficial effect of integrated fertilizing systems in increasing the available nutrients, improving photosynthesis, better distributing photosynthetic substances to sinks, and improving crop growth. The 100-seed weight and the pod number per plant were highly significantly correlated (Tab. 6). The lower 100-seed weight in treatment $T_{5}$ (nitrogen-fixing bacteria + triple superphosphate fertilizer) may be due to the limited availability of nutrients in post-blooming stages; this greatly decreased the plants' ability to produce photosynthesis substances. This may be due to the harmful effects of chemical fertilizer, which offer inappropriate nutrients to provide enough substances within the seeds. Sufficient rainfall at Mahidasht (Tab. 2) enhanced the vegetative growth of annual medic var. 'Robinson', produced adequate photosynthetic substances for seed reserves, promoted the growing period and ultimately led to a higher 100 -seed weight (Tab. 4).

\section{Pod yield}

Pod yield was significantly influenced by experimental location, fertilizing systems and their interactions (Tab. 3). The highest pod yield was obtained by applying nitrogenfixing bacteria + mycorrhiza $(445 \mathrm{~kg} / \mathrm{ha})$. The lowest yield was obtained in the control treatment (266 kg/ha; Tab. 5 ). The effect of biological fertilizers containing phosphatesolubilizing bacteria on the yield of agricultural crops has been investigated by De Freitas (2000) on wheat and by Ferrettin et al. (2004) on barley and sugar beet. The over- 
Tab. 5. Affect of different fertilizing systems on pod yield, pod P-content and P-uptake at two experimental research stations

\begin{tabular}{|c|c|c|c|c|c|c|c|c|c|}
\hline \multirow{3}{*}{ Treatment } & \multicolumn{3}{|c|}{ Pod yield (kg/ha) } & \multicolumn{3}{|c|}{ Pod P-content (\%) } & \multicolumn{3}{|c|}{ P-uptake (g/ha) } \\
\hline & \multicolumn{2}{|c|}{ Location } & \multirow{2}{*}{ Mean } & \multicolumn{2}{|c|}{ Location } & \multirow{2}{*}{ Mean } & \multicolumn{2}{|c|}{ Location } & \multirow{2}{*}{ Mean } \\
\hline & $\mathrm{L}_{1}$ & $\mathrm{~L}_{2}$ & & $\mathrm{~L}_{1}$ & $\mathrm{~L}_{2}$ & & $\mathrm{~L}_{1}$ & $\mathrm{~L}_{2}$ & \\
\hline $\mathrm{T}_{0}$ & 200 & 332 & $266^{f}$ & 0.160 & 0.160 & $0.160^{f}$ & 320 & 528 & $424^{f}$ \\
\hline $\mathrm{T}_{1}$ & 303 & 489 & $395^{\mathrm{b}}$ & 0.260 & 0.160 & $0.210^{\mathrm{c}}$ & 787 & 784 & $785^{\mathrm{cd}}$ \\
\hline $\mathrm{T}_{2}$ & 260 & 454 & $356 b^{c}$ & 0.260 & 0.310 & $0.285^{b c}$ & 678 & 1402 & $1040^{\mathrm{abc}}$ \\
\hline $\mathrm{T}_{3}$ & 247 & 377 & $312^{\mathrm{cd}}$ & 0.260 & 0.310 & $0.285^{\mathrm{bc}}$ & 644 & 1171 & $907^{\mathrm{cd}}$ \\
\hline $\mathrm{T}_{4}$ & 250 & 454 & $352^{\mathrm{cd}}$ & 0.260 & 0.260 & $0.263^{\mathrm{cd}}$ & 672 & 1176 & $924^{\mathrm{bcd}}$ \\
\hline $\mathrm{T}_{5}$ & 213 & 397 & $305^{\mathrm{cf}}$ & 0.210 & 0.260 & $0.235^{\mathrm{dc}}$ & 445 & 1034 & $739^{c}$ \\
\hline $\mathrm{T}_{6}$ & 278 & 423 & $350^{\mathrm{cd}}$ & 0.370 & 0.310 & $0.340^{\mathrm{a}}$ & 1038 & 1310 & $1174^{\mathrm{a}}$ \\
\hline $\mathrm{T}_{7}^{0}$ & 460 & 431 & $445^{a}$ & 0.306 & 0.210 & $0.258^{\mathrm{cd}}$ & 1411 & 906 & $1159^{a}$ \\
\hline $\mathrm{T}_{8}$ & 220 & 518 & $368^{\mathrm{bc}}$ & 0.370 & 0.260 & $0.315^{\mathrm{ab}}$ & 806 & 1341 & $1073^{\mathrm{ab}}$ \\
\hline Mean & $270^{\mathrm{b}}$ & $430^{\mathrm{a}}$ & & $0.273^{\mathrm{a}}$ & $0.248^{\mathrm{b}}$ & & $755^{b}$ & $1072^{a}$ & \\
\hline $\mathrm{LSD}_{\text {localtirear }}(5 \%)$ & & & & & & & & & \\
\hline
\end{tabular}

$\mathrm{T}_{0}$ : Control (no fertilizer application); $\mathrm{T}_{1}$ : Chemical fertilizer $\left(135 \mathrm{~kg} / \mathrm{ha}\right.$ urea fertilizer $+185 \mathrm{~kg} /$ ha triple superphosphate fertilizer); $\mathrm{T}_{2}:$ Urea chemical fertilizer + phosphorus-solubilizing bacteria; $\mathrm{T}_{3}$ : urea chemical fertilizer + mycorrhiza; $\mathrm{T}_{4}$ : urea chemical fertilizer + phosphorus-solubilizing bacteria + mycorrhiza; $\mathrm{T}_{5}:$ Nitrogen -fixing bacteria + triple superphosphate fertilizer; $\mathrm{T}_{6}$ : Nitrogen-fixing bacteria + phosphorus-solubilizing bacteria; $\mathrm{T}_{7}$ : nitrogen-fixing bacteria + mycorrhiza;

$\mathrm{T}_{8}$ : Nitrogen-fixing bacteria + phosphorus-solubilizing bacteria + mycorrhiza

all conclusion of these experiments is that applying phosphate-solubilizing bacteria on these crops significantly increased the seed yield and its components as well as the total dry matter. Ferrettin et al. (2004) demonstrated the positive effects of chemical fertilizers and P-solubilizing bacteria application on sugar beet and barley yields.

\section{Phosphorus content in pods}

Phosphorus content in annual medic pods was significantly affected $(P<0.05)$ by different fertilizing treatments (Tab. 3). All treatments had a higher phosphorus content in the pods compared to the control. The highest content $(0.34 \%)$ was found in treatment $\mathrm{T}_{6}$ (nitrogen-fixing bacteria + phosphorus-solubilizing bacteria; Tab. 5). When chemical fertilizers are applied, most of the $\mathrm{P}$ becomes unavailable to the plants due to surface absorption and sedimentation (Ghosh et al., 2004). In both experimental sites, soil Ca content was high (Tab. 1), which tended to convert most of the P added by chemical fertilizer to complex compounds unavailable for plant absorption. The positive effects of P-solubilizing bacteria on shoot dry weight, seed yield and seed N, P, and K content were reported by Rasipour and Aliasgharzadeh (2007).
The present experiment showed that a significant interaction effect $(P<0.01)$ of different fertilizing systems and experimental sites on the phosphorus content in pods (Tab. 5). These results confirm the findings of Mitra et al. (1999) and Rodrigez and Rinaldo (1999), who reported positive effects of biological fertilizers containing phosphate-solubilizing bacteria on increasing the nutrient content, especially of phosphorus, in plants.

\section{Pod phosphorus uptake}

The amount of phosphorus uptake by pods, calculated by multiplying pod yield and pod phosphorus content (percentage), was significantly influenced by fertilizing treatments (Tab. 3). The highest pod phosphorus uptake was found in treatments using nitrogen-fixing bacteria + phosphorus-solubilizing bacteria $\left(\mathrm{T}_{6}\right)$ and nitrogen-fixing bacteria + mycorrhiza $\left(\mathrm{T}_{7}\right)$, the lowest uptake in the control treatment ( $424 \mathrm{~g} / \mathrm{ha}$; Tab. 5). Poberejskaya and Egamberdiyeva (2003), applying bacteria along with superphosphate fertilizer to cotton, significantly increased plant dry matter, the absorption of nitrogen, potassium and phosphorus, and also increased the amount of soilavailable phosphorus. This result has been supported by

Tab. 6. Simple correlation coefficients between agronomic traits of annual medic as affected by different fertilizing systems under dry farming conditions

\begin{tabular}{|c|c|c|c|c|c|c|c|c|}
\hline Row & Trait & 1 & 2 & 3 & 4 & 5 & 6 & 7 \\
\hline 1 & Pod per plant (no) & 1 & & & & & & \\
\hline 2 & Soil seed bank $\left(\mathrm{no} / \mathrm{m}^{2}\right)$ & $0.49^{* *}$ & 1 & & & & & \\
\hline 3 & 100-seed weight $(\mathrm{g})$ & $0.30^{*}$ & $-0.29^{*}$ & 1 & & & & \\
\hline 4 & Pod yield (kg/ha) & $0.72^{* *}$ & $0.73^{* *}$ & $-0.04^{\mathrm{ns}}$ & 1 & & & \\
\hline 5 & A. g. biomass $(\mathrm{kg} / \mathrm{ha})$ & $0.46^{* *}$ & $0.62^{* *}$ & $0.53^{* *}$ & $0.62^{* *}$ & 1 & & \\
\hline 6 & P-concentration (\%) & $0.15^{\mathrm{ns}}$ & $0.17^{\mathrm{ns}}$ & $-0.20^{\mathrm{ns}}$ & $-0.01^{\mathrm{ns}}$ & $-0.02^{\mathrm{ns}}$ & 1 & \\
\hline 7 & P-absorption (g/ha) & $0.69^{* *}$ & $0.56^{* *}$ & $0.31^{*}$ & $0.45^{* *}$ & $0.76^{* *}$ & $0.59^{* *}$ & 1 \\
\hline
\end{tabular}


196

Mitra et al. (1999) on mung bean. Those authors also concluded that the increments in the availability of absorbable phosphorus in the soil enhance the absorption of other elements such as potassium by the plant. This phenomenon explains why, if the soil is nutrient rich (Tab. 1), that the effect of biological fertilizers on increasing the yield diminishes; conversely, as soil fertility decreases, the effect of biological fertilizers on increasing the yield increases. This may reflect the higher activity of phosphate solubilizing bacteria in poor soils, which is followed by an increase in absorbable phosphorus. The positive effects-root development and enhanced $\mathrm{N}$ and $\mathrm{P}$ absorption-of co-applying $\mathrm{N}$-fixing bacteria (Rhizobium sp.) and mycorrhiza fungi ( $G$. fasciculatum) on lentil in the same soil conditions was reported by Zaidi et al. (2004).

The present study underlines that, in conditions similar to those in this experiment, the inoculation of annual medic var. 'Robinson' seed with nitrogen-fixing bacteria + phosphorus-solubilizing bacteria increases the pod phosphorus content and soil seed bank. Under dryland farming conditions, the synergetic effect of nitrogen-fixing bacteria and phosphorus-solubilizing bacteria on annual medic (var. 'Robinson') seed system was evident.

The interaction effects of experimental site and fertility treatments showed the highest pod production in the $\mathrm{T}$ treatment. The biological fertilizers including $\mathrm{T}_{4}$ are apparently better adapted to different site climatic and soil conditions and can produce higher yields and yield components. Ehteshami (2007), studying different phosphorus microbial fertilizers on corn production under limited irrigation systems, concluded that corn plants inoculated by Pseudomonas fuorescens and Glomus intraadices performed better under such systems compared to the control (normal irrigation). These results indicate that biological fertilizers can modify the adverse effects of moisture stress conditions. Our results showed that annual medic (Medicago scutellata) inoculated by different microbial fertilizers which requires more time to achieve its potential yield production under a dry farming system.

Considerable forage yields were produced experimentally when annual medic received different fertilizing treatments in spring cultivation. The best treatment should produce not only a reasonable forage yield but also enough pods (in the soil seed bank) to guarantee a successful regeneration in the following growing season. If the main goal is optimal forage production, then the application of the $\mathrm{T}_{8}$ fertilizing treatment (nitrogen-fixing bacteria + phosphorus-solubilizing bacteria + mycorrhiza) is recommended. If, however, natural regeneration must also be considered, then the $\mathrm{T}_{6}$ treatment (nitrogen-fixing bacteria + phosphorus-solubilizing bacteria) is highly recommended

\section{Acknowledgements}

The authors would like to thank the personnel of the Water and Soil Research of Kermanshah Agriculture and
Natural Resources Center and the (Sararood) Dryland Research Institute for their cooperation in carrying out the project.

\section{References}

Al-Karaki Gh, McMichael B, Zak J (2003). Field Response of Wheat to Arbuscular Mycorrhiza Fungi and Drought Stress. Mycorrihiza 14:263-269.

Cardoso IM, Kuyper TW (2006). Mycorrhizas and Tropical Soil Fertility. Agri Eco Environ 116:72-48.

Chen J (2006). The Combined Use of Chemical and Organic Fertilizers and/or Biofertilizer for Crop Growth and Soil Fertility. International Workshop on Sustained Management of the Soil-Rhizosphere System for Efficient Crop Production and Fertilizer Use. October, p. 16-20.

Christiansen S, Cocks PS (1994). Change in Seed Bank Size and Botanical Composition of Medic Pastures Grown in Rotation with Barley in North-West Syria. Al Awamia 87:141-148.

De Freitas JR (2000). Yield and N Assimilation of Winter Wheat (Triticum aestivum L., var 'Norstar') Inoculated with Rhizobacteria. Pedobiologia 44:97-104.

Donald CM (1967). The Impact of Cheap Nitrogen. J Austr Inst Agri Sci 26:319-338.

Ebhin Masto R, Chhonkar PK, Singh D, Patra AK (2006). Changes in Soil Biological and Biochemical Characteristics in Long-term Field Trial on a Sub-tropical Incept Soil. Soil Bio Biochem 38:1477-1582.

Ehteshami M (2007). Effect of Biological Phosphate Fertilizers on the Qualitative and Quantitative Indes of Corn by Water Deficit. PhD thesis, Tarbiat Modarres University, p. 269.

Elwan LM (2001). Effect of Soil Water Regimes and Inoculation with Mycorrhizae on Growth and Nutrients Content of Maize Plants. Zagazing J Agric Res 28:162-172.

Ferrettin S, Cakmakci R, Kanter F (2004). Suger Beet and Barley Yield in Relation to Inoculation with $\mathrm{N}_{2}$-Fixing and Phosphate Solubilizing Bacteria. Plant Soil 256:123-129.

Francis CM (1988). Selection and Agronomy of Medics for Dry Land Pasture in Iran. Project Tcp/IRAN/6652.

Ghosh PK, Ramesh P, Bandyopadhy KK, Tripathi AK, Hati KM Misra AK (2004). Comparative Effectiveness of Cattle Manure, Poultry Manure, Phosphocompost and FertilizerNPK on Three Cropping Systems in Vertisoils of Semiarid Tropics. I. Crop Yields and Systems in Performance. Bioresource Tech 95:77-83.

Kassaim KK (1979). Study on Some Factors Affecting the Establishment of Annual Medics (Medicago sp.) under Rainfed Region in North Iraq. Mosul University Collage of Agriculture and Forestry, pp 155.

Mitra S, Bhattacharya SK, Datta M, Banils S (1999). Effect of Variety, Rock Phosphate and Phosphate Solubilizing Bacteria on Growth and Yield of Green Gram in Arid Soils of Tripura. Environ Ec 17:926-930. 
Nadian H, Smith SE, Alston AM, Murray RS (1998). Effect of Soil Compaction on Plant Growth, Phosphorus Uptake and Growth of Trifolium subterraneaum Colonized by Four Species of Vesicular- Arbuscular Mycorrizal Fungi. New Phtologist 139:155-156.

Neumann E, George E (2004). Colonization with the Arbucluar Mycorriza Fungus Glomus mosseae (Nicol and Gerd) Enhanced Phosphorus Uptake from Dry Soil in Sorghum Bicolor (L.). Plant Soil 261(1-2):245-255.

Olsen SR, Sommers LE (1990). Phosphorus, p. 403-431. In: Page ASL et al. (Eds.). Methods of Soil Analysis. Part 2.2. Agron. Monogor ed., Madison, WI.

Piccini D, Azcon R (1987). Effect of Phosphate-Solubilizing Bacteria and Vesical Arbuscular Mycorrhizal Fungi on the Utilization of Bayovar Rock Phosphate by Alfalfa Plants Using a Sand- Vermicailte Medium. Plant Soil 101:45-50.

Poberejskaya SL, Egamberdiyeva D (2003). Improvement of the Productivity of Cotton by Phosphate Solubilizing Bacterial Inoculants. Plant Nutri. Food Secur. Sustain. Agroeco 670671.

Rajendran K, Devaraj P (2004). Biomass and Nutrient Distribution and Their Return of Casuarina equisetifolia Inoculated with Biofertilizers in Farm Land. Biomass and Bioenergy 26:235-249.

Rasipour L, Aliasgharzadeh NA (2007). Interactive Effect of Phosphate Solubilizing Bacteria and Bradyrhizobium japonicum on growth, Nodule Indices and Some Nutrient Uptake of Soybean. J Sci Technol Agric Natur Resour 11(40):53-63.
Rodelas B (1999). Influence of Rhizobium Azotobacter Combined Inculcation on Mineral Composition of Faba Bean (Vicia faba L.). Biol Fer Soil 29(2):165-169.

Rodriguze H, Rinaldo RF (1999). Phosphate Solubilizing Bacteria and their Role in Plant Growth. Promotion Biotech Adv 17:319-339.

Vamerali TMS, Guarise N, Ganis A (2003). A Comparison of Root Charactertics in Relation to Nutrient and Water Stress in Two Maize Hybrids. Plant Soil 25:157-167.

Vessey JK (2003). Plant Growth Promoting Rhizobacteria as Biofertilizers. Plant Soil 25:571-586.

Wasule DL, Wadyalkar SR, Buldo AN (2002). Effect of Phosphate Solubilizing Bacteria on Tricalium Phosphate Containing Media. Proceeding of $15^{\text {th }}$ international meeting on microbial phosphate solubilization. Salamanaca University, 16-19 July, Salamanca, Spain.

Weston EJ, Dalal RC, Sttrong WM, Lehano KJ, Cooper JE, King AH, Mohammad A (1996). Depletion and Recharge of Available Soil Water at Warra in Southern Queensland. Proceeding of the $8^{\text {th }}$ Australian Agronomy Conference, Toowoomba, Queensland, and Australian. Aust Soci Agron 578-581.

Zahra IT, Loynachan TE (2003). Endomycorrhizal Fungi Survival in Continuous Corn, Soybean and Fallow. Agron J 95(1):224-230.

Zaidi A, Khan MS, Aamil M (2004). Bioassociative Effect of Rhizospheric Microorganisms on Growth, Yield and Nutrient Uptake of Greengram. J Plant Nutr 27:599-610. 